\title{
PENGARUH METODE TUTOR SEBAYA DALAM PEMBELAJARAN KELAS V SD N MANGUNSARI 06
}

\begin{abstract}
Abstrak
Penelitian pengaruh metode tutor sebaya dalam pembelajaran kelas V di Sekolah Dasar Negeri Mangunsari 06 Kota Salatiga bertujuan untuk mengetahui bagaimana peningkatan belajar pada siswa dalam menggunakan metode pembelajaran tutor sebaya di dalam kelas dan mengetahui pengaruh metode pembelajaran tutor sebaya dalam pembelajaran kelas V SD N Mangunsari 06 Kota Salatiga. Metode penelitian yaang digunakan yaitu metode wawancara. Hasil penelitian yang telah dilakukan adalah siswa lebih aktif dan kreatif berpikir dengan adanya metode tutor sebaya. Hal ini berarti bahwa terdapat pengaruh meningkatnya minat belajar siswa dengan menggunakan metode tutor sebaya dalam pembelajaran. Oleh sebab itu dalam penggunaan metode pembelajaran tutor sebaya lebih efektif dan menyenangka bagi siswa.
\end{abstract}

Kata Kunci: Prestasi, Tutor Sebaya, Belajar.

\begin{abstract}
Research on the effect of peer tutoring methods in 5th grade learning inSD Negeri Mangunsari 06 Salatiga city aims to find out how improvement in learning in students in using peer tutoring learning methods in the classroom and knowing the effect of peer tutoring learning method in 5th grade learning SD Negeri Mangunsari 06 Salatiga city. The research method used is the interview method. The results of the research that have been conducted are that students more active and creative thinking in the presence of peer tutoring methods. This means that there is an effect of increasing students learning interest with peer tutoring methods in learning. Therefore, in using peer tutoring learning methods more effective and fun for students.
\end{abstract}

Keywords: Achievement, peer tutor, learn.

\footnotetext{
${ }^{1}$ Pendidikan Guru Sekolah Dasar, Fakultas Keguruan dan Ilmu Pendidikan, Universitas Kristen Satya Wacana

Alamat email 292016128@ student.uksw.edu
} 


\section{PENDAHULUAN}

Pembelajaran yang baik adalah pembelajaran yang berlangsung dengan adanya keterlibatan peserta didik (siswa) secara aktif. Keaktifan siswa dapat didorong dengan menumbuhkan minat belajar pada siswa dalam pembelajaran. Dengan adanya minat belajar maka siswa akan termotivasi untuk rajin belajar, sehingga pemahaman siswa tentang materimateri yang diajarkan akan meningkat, dan keberhasilan siswa dalam belajar dapat tercapai. Salah satu faktor yang dapat mempengaruhi hasil belajar seseorang yaitu, kemampuan guru (profesionalisme guru) dalam mengelola pembelajaran dengan metode-metode yang tepat.

Dalam pembelajaran, suasana kelas yang positif akan terjadi bila adanya interaksi dalam kelas antara guru dan siswa, antara siswa dan siswa, di mana dalam interaksi itu terjadi komunikasi dalam bentuk kerjasama, tolong-menolong, tenggang rasa antara anak yang pandai dan yang kurang pandai, dan lainnya. Dengan demikian, akan terjadi suasana kelas yang selalu menyenangkan, di mana tiap orang berusaha menghargai dan menghargai pendapat orang lain sebagaimana adanya bukan sebagaimana nampaknya.

Metode pembelajaran yang cocok dalam interaksi di kelas tersebut adalah tutor sebaya (peer teaching), karena adanya interaksi yang penuh antara siswa dalam kegiatan belajarmengajar, dimana siswa tersebut ada yang berperan sebagai pendidik dan siswa yang lain berperan sebagai peserta didik. Tutor sebaya dikenal dengan pembelajaran teman sebaya atau antar peserta didik. Hal ini bisa terjadi ketika peserta didik yang lebih mampu menyelesaikan pekerjaannya sendiri dan kemudian membantu peserta di dik lain yang kurang mampu. Dalam tutor sebaya (peer teaching), peranan guru sebagai fasilitator dan pembimbing terbatas. Artinya, guru hanya melakukan intervensi ketika dalam pembelajaran.

Dengan penggunaan metode pembelajaran tutor sebaya (peer teaching), para siswa dapat menumbuhkan dan meningkatkan minat belajar mereka, sehingga materi-materi pelajaran yang diberikan dapat dipahami, karena penjelasan materi pelajaran melalui tutor sebaya (peer teaching) menggunakan bahasa yang lebih akrab dan peserta didik melihat masalah dengan cara yang berbeda dibandingkan orang dewasa. Dengan meningkatnya minat belajar siswa maka keberhasilan belajar siswa akan tercapai. Jadi, keberhasilan belajar dalam proses pembelajaran melalui tutor sebaya (peer teaching) bukan hanya ditentukan oleh kemampuan individu, tetapi merupakan hasil bersama-sama dalam kelompok kecil atau besar yang terstruktur dengan baik. Keberhasilan belajar siswa berarti tercapainya tujuan belajar siswa. Tujuan belajar siswa dalam proses pembelajaran adalah perubahan prestasi belajar mereka yang lebih baik daripada sebelumnya. Dengan metode pembelajaran tutor sebaya (peer teaching) diharapkan dapat memberikan hasil yang lebih baik dan lebih bermakna dalam pencapaian prestasi belajar siswa dibandingkan dengan pembelajaran konvensional.

Pembelajaran konvensional merupakan suatu istilah pembelajaran yang dilakukan sehari-hari di sekolah. Dalam pembelajaran konvensional ini, keaktifan siswa dalam proses pembelajaran kurang dirasakan dan juga jarang memotivasi siswa dalam proses pengetahuannya, maksudnya transfer ilmu pengetahuan secara utuh dipindahkan dari pikiran guru ke pikiran siswa. Jadi, siswa hanya menerima ilmu pengetahuan dari guru di sekolah. Oleh karena itu, para guru banyak menerapkan metode pembelajaran baru yang sesuai dengan perkembangan dunia pendidikan dan dapat melibatkan keaktifan siswa dalam proses pembelajaran, salah satunya adalah tutor sebaya (peer teaching). 
Penelitian ini yang diteliti bagaimana pengaruh dari penggunaan metode tutor sebaya dalam pembelajaran di SD Negeri Mangunsari 06 ? Dalam dilakukannya penelitian ini diharapkan dapat berguna dan bermanfaat bagi pendidik atau calon guru dalam melakukan pembelajaran, penelitian ini bermanfaat untuk mengetahui bahwa terdapat pengaruh penggunakan metode tutor sebaya dalam pembelajaran itu dapat meningkatkan prestasi siswa, dan siswa lebih kreatf dalam belajar.

\section{METODE}

Metode penelitian yang digunakan dalam penelitian ini adalah metode wawancara, dimana dengan melakukan metode wawancara ini kita dapat mengetahui pengaruh dampak belajar dengan menggunakan metode tutor sebaya ini. Metode wawancara dalam penelitian ini dilakukan dalam proses pembelajaran yang telah dilaksanakan. Metode ini digunakan dengan cara menguji perbandingan siswa lebih aktif atau tidak dalam belajar dengan menggunakan metode tutor sebaya.

\section{HASIL DAN PEMBAHASAN}

Dari hasil pengolahan data, dapat disimpulkan bahwa pengunaan media pembelajaran lebih disukai peserta didik.

\begin{tabular}{|l|c|c|c|c|}
\hline No & Setuju & Presentase & $\begin{array}{c}\text { Tidak } \\
\text { Setuju }\end{array}$ & Presentase \\
\hline 1 & 12 & 60 & 8 & 40 \\
\hline 2 & 14 & 70 & 6 & 30 \\
\hline 3 & 11 & 55 & 9 & 45 \\
\hline 4 & 16 & 80 & 4 & 20 \\
\hline 5 & 11 & 55 & 9 & 45 \\
\hline 6 & 15 & 75 & 5 & 25 \\
\hline 7 & 13 & 65 & 7 & 35 \\
\hline 8 & 12 & 60 & 8 & 40 \\
\hline 9 & 15 & 75 & 5 & 25 \\
\hline 10 & 17 & 85 & 3 & 15 \\
\hline
\end{tabular}




\begin{tabular}{|l|l|l|l|}
\hline No & Rentang Nilai & Frekuensi & \multicolumn{1}{|c|}{$\begin{array}{c}\text { Presentase } \\
(\%)\end{array}$} \\
\hline 1 & $0-49$ & 0 & 0 \\
\hline 2 & $50-79$ & 6 & 30 \\
\hline 3 & $80-100$ & 14 & 70 \\
\hline Total & & 20 & $100 \%$ \\
\hline
\end{tabular}

Tabel diatas menunjukan bahwa lebih banyak peserta didik telah mencapai KKM 70\%, dengan penggunaan metode tutor sebaya peserta didik lebih banyak yang mencapai KKM.

Dalam penelitian menggunakan metode angket untuk mengetahui pengaruh metode tutor sebaya dalam pembelajaran ini lebih tinggi siswa aktif dalam belajar, tidak hanya aktif siswa juga lebih kreatif, dan meningkatkan kecakapannya dalam berkomunikasi, siswa juga rasa ingin tahu nya lebih tinggi. Dalam tabel angket yang telah dibuat peneliti bahwa siswa dapat menciptakan rasa toleransi sesama mencapai $60 \%$ siswa, siswa yang berpikir kreaatif dalam belajar berdiskusi mencapai $70 \%$ siswa, siswa lebih tekun belajar dan rajin dapat mencapai presentase 55\% siswa, siswa menjadi ketergantungan dengan temannya yang lebih aktif mencapai presentase $40 \%$, siswa juga dapat memberikan umpan balik antar sesama siswa dalam berdiskusi mencapai $80 \%$, siswa menjadi tidak takut bertanya dalam berdiskusi walaupun kadang pertanyaannya tidak masuk akal jadi siswa juga terlatih percaya diri dengan pertanyaanpertanyaan yang disampaikan mencapai presentase $60 \%$, minat belajar siswa lebih meningkat dengan menerapkan metode tutor sebaya mencapai presentase 60\%. Dari penelitian ini bahwa pengaruh metode tutor sebaya dalam pembelajaran sangat berpengaruh pada minat, prestasi belajar peserta didik lebih aktif, kreatif dan menyenangkan serta minat belajar siswa lebih tinggi dibandingkan dengan pembelajaran yang konvensional.

Pada penelitian ini, peningkatan minat belajar siswa yang lebih baik karena beberapa hal positif dalam metode tutor sebaya (peer teaching), yaitu: (1) Dengan pembelajaran tutor sebaya (peer teaching), rasa ingin belajar meningkat karena setiap siswa yang berperan sebagai tutor harus menguasai materi pembelajaran yang akan diberikan, sehingga mereka tekun dalam mempelajari materi tersebut, (2) Pembelajaran tutor sebaya meningkatkan konsentrasi belajar siswa, sehingga materi pembelajaran menjadi lebih mudah dan cepat dipahami, (3) Pembelajaran tutor sebaya meningkatkan semangat belajar siswa, sehingga permasalahan yang ditemukan selama pembelajaran dapat dipecahkan dalam berdiskusi, (4) Pembelajaran tutor sebaya meningkatkan rasa ingin tahu siswa dalam belajar, sehingga para siswa berpartisipasi aktif dalam kegiatan 
belajar, dan (5) Pembelajaran tutor sebaya merupakan pembelajaran yang menyenangkan.

Hasil pengolahan data laporan prestasi belajar peserta didik kelas 05 dengan menggunakan metode tutor sebaya dalam pembelajaran menunjukkan bahwa prestasi belajar sudah bagus.

\section{SIMPULAN}

Berdasarkan hasil penelitian dalam meningkatkan minat dan prestasi belajar siswa, saran-saran yang dapat penulis berikan adalah sebagai berikut: (1) Berdasarkan hasil penelitian, penerapan metode pembelajaran tutor sebaya (peer teaching) dapat meningkatkan minat dan prestasi belajar siswa. Oleh sebab itu, dalam pembelajaran sebaiknya menggunakan metode pembelajaran tutor sebaya (peer teaching); (2) Metode pembelajaran tutor sebaya merupakan salah satu alternatif terbaik untuk menarik perhatian siswa dalam belajar, sehingga siswa dapat lebih berpartisipasi aktif dalam pembelajaran; (3) Metode pembelajaran tutor sebaya merupakan suatu cara yang dapat digunakan untuk memberikan pengalaman secara langsung kepada siswa mengajar, sehingga siswa dapat lebih percaya diri, lebih berani, lebih bertanggung jawab, dan saling berbagi pengetahuan; dan (4) Metode pembelajaran tutor sebaya dapat pula digunakan untuk penelitian lain yang menggunakan metode ini untuk meningkatkan minat dan prestasi belajar siswa yang bermanfaat baik bagi guru maupun siswa.

\section{DAFTAR PUSTAKA}

Hafizah, E. (http://jurnal.untan.ac.id/index.php/jpdpb/article/view/1047/pdf). http://jurnal.untan.ac.id/index.php/jpdpb/article/view/1047/pdf.

Haryani, M. (n.d.). http://eprints.radenfatah.ac.id/1221/1/MERLY\%20HARYANI\%20\%28.pdf. http://eprints.radenfatah.ac.id/1221/1/MERLY\%20HARYANI\%20\%28.pdf, 7-8.

Riani, D. R. (n.d.). Pengaruh Model Pembelajaran Tutor Sebaya Terhadap Hasil Belajar Siswa Pada Mata Pelajaran IPS Kelas IV SD Negeri 2 Way Huwi. Pengaruh Model Pembelajaran Tutor Sebaya Terhadap Hasil Belajar Siswa Pada Mata Pelajaran IPS Kelas IV SD Negeri 2 Way Huwi. 